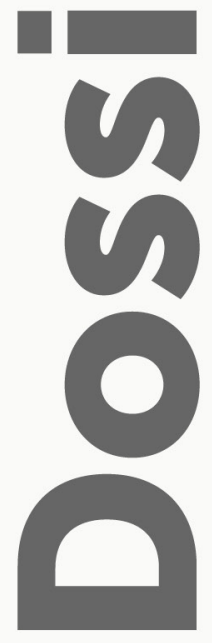

\title{
Um olhar antropológico sobre o suicídio: devir, formas de vida e subjetividades
}

\author{
An anthropological view about suicide: \\ becoming, forms of life and subjectivities
}

\section{RESUMO}

O objetivo deste artigo é refletir sobre o fenômeno do suicídio, a partir de alguns referenciais teóricos antropológicos e de uma etnografia realizada em ambiente digital, entre 2014 e 2016, que resultou em uma tese de doutorado. Em um primeiro momento, explicita-se como é possível inscrever o suicídio em uma análise social, por meio de certos conceitos, como formas de vida, subjetividades e devir. A seguir são apresentados alguns sujeitos etnográficos e são analisados seus discursos de suicídio como uma forma de perda de um futuro imaginado, à luz de teorias recentes da antropologia fundamentadas nas subjetividades e nas experiências do sujeito. Assim, propõe-se uma mudança no entendimento do fenômeno do suicídio capaz de englobar também uma perspectiva multidisciplinar: mais do que um Mal a ser combatido a qualquer custo, o suicídio é, ao mesmo tempo, uma resposta e uma consequência, entranhadas na vida social e cultural, de violências e de sofrimentos sociais. Nesta intepretação, o suicídio pode ser entendido como ausência do devir ou como um devir extremo. Por fim, um olhar antropológico permite ampliar a compreensão do fenômeno, que deixa de ser somente um item nosográfico e passa a ser um elemento indissociável da experiência humana.

Palavras-chave: Suicídio - Antropologia - Formas de vida - Subjetividades - Biopolítica

\begin{abstract}
The aim of this paper is to make a reflection about the suicide phenomenon based on some anthropological readings, and via a digital ethnography, made between 2014 and 2016, that resulted in my PhD thesis. First, it's shown the possibilities social analyses bring to the understanding of the phenomenon, through concepts such as forms of life, subjectivities and becoming. Then, the reader is introduced to ethnographical subjects to analyze their suicide discourses as a loss of an imagined future, in accordance with recent theories of Anthropology that are grounded on subjectivities and the subject daily experience. In this way, it is proposed that the suicide phenomenon should be read not as an Evil to be fought no matter what, but as a response against violence and social suffering, that is entangled in social life and culture. In this interpretation, suicide can be understood as the absence of becoming or as an extreme form of becoming. This anthropological view enables to expand the understanding on what suicide is; no more just a nosographical item, but also an indissociable element of human experience.
\end{abstract}

Keywords: Suicide - Anthropology - Forms of life - Subjectivities Biopolitics cnpq.br/0893686645749911. 
Essa talvez tenha sido a última vez em que ela o viu. Porque eles pararam de ir lá. O Sr. Coldfield parou. Nunca houvera um dia certo para a visita. Alguma manhã, ele simplesmente aparecia para tomar café da manhã usando o casaco pesado preto e decente com o qual se casara e que havia usado cinquenta e duas vezes por ano desde que Ellen se casara, e depois cinquenta e três vezes por ano desde que a tia os desertara, até que o vestiu para sempre no dia em que subiu ao sótão e pregou a porta por dentro e atirou o martelo pela janela e assim morreu com ele.

William Faulkner, Absalão, Absalão! (2014)

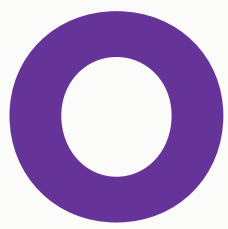

que é o suicídio? A pergunta parece, à primeira vista, um tanto simples, e sua resposta pode ser formulada em uma ou duas linhas. $\bigcirc$ "ato de causar a própria morte" pode satisfazer leitores mais apressados ou desinteressados, pode até simplificar a ação de quem trabalha na linha de frente na área da Saúde e de quem lida com o suicídio na rotina de um hospital. Contudo, esta resposta esconde e enterra a própria pergunta. Há quem não veja a necessidade de filosofar ou problematizar o termo, mas mesmo para quem busca respostas na superfície não resta muita opção: debruçar-se numa investigação sobre o tema envolve não somente pensar nas ações humanas e nas experiências no Planeta Terra. Também implica em questões que levam em consideração a morte e a Vida, este substantivo maiúsculo que diz respeito a tudo o que somos e tudo o que conhecemos. Portanto, a indagação que abre o parágrafo não tem resposta objetiva, e talvez não mereça uma resposta objetiva.

O que nos leva a outra pergunta: como investigar e pesquisar algo que não tem uma simples definição objetiva? Já esta questão só pode ser respondida com uma inversão da lógica do que se pesquisa. Depende da abordagem que se tem, mas o foco não é, necessariamente, o suicídio per se: quando investigamos suicídio, na realidade, estudamos as adjacências do fenômeno por meio da lente que escolhemos - porque olhar somente para o suicídio é como olhar para um fractal, aquela figura cuja estrutura se mantem idêntica, não importa o quanto nos afastamos ou nos aproximamos dela. Mais que o resultado da imagem final, para o fractal tem importância a estrutura e a força que o gera. Então, quando estudamos suicídio, estamos estudando as ações que conduzem os sujeitos até uma morte voluntária. Há diversas lentes clássicas, grosso modo: a Epidemiologia busca curvas comuns e causas; a Psiquiatria busca relações de causa e consequência em itens nosográficos; a Psicologia busca entender comportamentos; a Genética busca entender a influência de alguns genes no desequilíbrio neuroquímico. Há, também, o senso comum, que situa a causa no indivíduo, ruminando estigmas e tabus.

Além disso, há, de certo modo, uma escassez de estudos dirigidos a compreender o suicídio por meio de abordagens filosóficas ou antropológicas. Embora o tema tenha sido central nas formulações sociológicas de Émile Durkheim (2008) há mais de um século, a carência de pensamentos sobre o fenômeno pode ser um indicativo que confirma sua conotação de tabu e de não-dito, mesmo no conjunto de estudos acadêmicos. O suicídio é um tema difícil de 
abordar inclusive nas ciências da saúde, muitas vezes a abordagem é reduzida unicamente a protocolos de ação junto a um paciente que tentou suicídio e que foi internado. Os números dão uma noção do quadro geral, porém são considerados subnotificados, o que significa que estariam abaixo do que seria a realidade, por motivos que abrangem desde a ineficiência dos sistemas de registros às dificuldades de preenchimento de fichas - muitas vezes, dificuldades imersas em percepções fundamentadas em opiniões pessoais.

Partindo deste preâmbulo, o objetivo deste artigo é refletir sobre o fenômeno do suicídio, com base em uma intepretação que considere algumas dimensões das ciências humanas, principalmente a antropologia crítica da saúde e a antropologia do devir, que abarcam como melodia comum o conhecimento sobre as subjetividades, os sofrimentos sociais e as formas de vida. Tal análise está longe de ser uma busca por um entendimento peremptório acerca do tema; mais que isso, é uma tentativa de inserir mais elementos e categorias de análise para uma compreensão que supere o senso comum e colabore para retirar o suicídio da esfera dos temas tabu em nossa sociedade.

Para cumprir este objetivo, o artigo se estrutura do seguinte modo: em um primeiro momento, são apresentadas algumas fundamentações teóricas sobre a vida, as regulações biopolíticas e as formas de vida, tal como a antropologia de devir; e, também, sobre a morte e as interseções do tema em que se encontra o suicídio. Para desenvolver a análise são apresentados alguns dados de pesquisa de doutorado (Nagafuchi, 2017) realizada a partir de uma etnografia em ambientes digitais, cujo núcleo se baseou nas relações entre suicídio, gênero e sexualidade. De modo geral, embora o foco da etnografia incidisse sobre as articulações do sofrimento social gerado a partir das identidades de gênero e das orientações afetivo-sexuais, a riqueza dos resultados permite que se construam entendimentos transcendentes em relação ao fenômeno do suicídio, enfatizando sua natureza social e cultural.

\section{Parte I - O suicídio: fenômeno multifatorial de definição incerta}

\section{Vida: biopolíticas, formas de vida, antropologia do devir}

Em estudos anteriores, Nagafuchi $(2017 ;$ 2018) e Nagafuchi e Adorno (2016) afirmavam ser possível classificar aqueles que tentaram uma morte voluntária de acordo com categorias de "suicidas". Porém, de certo modo, classificar pessoas como "suicidas" pode ser estigmatizante. É uma forma de incluir mais um estigma em um estigma. Considera-se melhor elaborar, então, o seguinte: a pessoa que tenta se matar opera em diversos discursos de suicídio, e estes são modos de comunicação não necessariamente verbais. O suicídio, lido segundo um viés socioantropológico, é um ato comunicativo (Marquetti, 2012; 2014). Portanto, diz algo sobre a pessoa, a sociedade e o mundo.

Este viés é, também, uma proposta de mudança no entendimento do fenômeno do suicídio, não apenas nas ciências sociais, de modo que englobe as diversas áreas de conhecimento de forma transdisciplinar: mais do que um Mal a ser combatido a qualquer 
custo, o suicídio é uma resposta e uma consequência dos sofrimentos sociais e da violência. Tal mudança torna-se fundamental para que as ações voltadas à prevenção, às pesquisas e à produção de conhecimento sobre o tema deixem de ter como solução única a medicalização e as intervenções compulsórias dos sujeitos e de seus comportamentos.

Quando inserimos o suicídio numa interpretação cultural, levando em consideração este viés, abrimos diversas possibilidades de análise e entendimento do fenômeno. Aqui, há intenção de realizar uma leitura das biopolíticas contemporâneas, ao considerar que "o suicídio é uma ruptura, que se dá nas margens da vida, nas intermitências das possibilidades de vida e, por isso, é sempre resultado de sua qualidade de liminaridade, de ação em direção à morte" (Nagafuchi, 2017, p. 121). Por ruptura entendemos que o que corrompe a vida ou suas condições é o que vamos nomear de perda de um futuro imaginado. ${ }^{1}$ Essa perda é também a aniquilação do mundo (Das, 2007), que transforma a experiência humana, considerada como uma forma de vida, em algo sem forma e sem vida.

"Formas de vida" é uma terminologia que surge na Filosofia da Linguagem de Ludwig Wittgenstein e nas leituras de Stanley Cavell (1997) e, mais recentemente, nos estudos antropológicos propostos por Veena Das (2007) e Didier Fassin (2018). Veena Das encontrou no termo composto um modo de entender a dor e o sofrimento social de suas interlocutoras enquanto resultados de eventos históricos críticos, como as violências originadas pela Partição da Índia e do Paquistão, e que, de alguma forma, seriam conhecimentos venenosos que ainda fazem parte do presente como tentáculos no cotidiano de suas vidas. Este esmagamento das subjetividades irrompe da negação das diversas experiências humanas porque é, também, a negação das formas de vida ao atribuir mais valor à forma do que à vida. Quando esta condição acontece, segundo Das (2007), os sujeitos são excluídos não somente das comunidades, mas da própria vida.

Para Fassin (2018), esta questão das formas de vida deve ser lida nas tensões da clássica dicotomia entre natureza e cultura. Se, para a Filosofia da Linguagem, as formas de vida seriam os modos de ser no mundo, para esta antropologia proposta por Fassin, a vida pode ser entendida por meio de uma dupla dimensão: com o $\mathrm{V}$ maiúsculo, como (i) organização universal da matéria ou, com o v minúsculo, como (ii) experiência de um ser em particular, que não necessariamente é humano; ou seja, vida como matéria viva ou como experiência vivida. Assim, Fassin localiza as formas de vida nas tensões entre o universal e o particular (transcendental versus antropológico); a biologia e a biografia (o que é vivo versus o que foi vivido); e a lei e a prática (regra versus liberdade). ${ }^{2}$

A partir desta tensão também surge a ideia da sacralidade da vida, como se ela fosse o bem supremo a que se ganha direito no momento do nascimento ${ }^{3}$. Neste sentido, a vida seria uma posse e, como tal, poderia sem qualquer limitação adquirir valores monetários (Fassin,

1 A expressão "perda de futuro imaginado", que pegamos emprestado, aparece de forma tangencial na introdução de Biehl \& Locke (2017), sobre a antropologia do devir.

Respectivamente, Fassin elabora tais dicotomias a partir de Wittgenstein, Canguilhem e Agamben.

3 Em alguns casos, como na discussão do direito ao aborto, há quem advogue que a sacralidade da vida teria início no momento impreciso da fecundação. 
2010; 2014; 2016). ${ }^{4}$ No entanto, olhando para o indivíduo vivo, a vida não o pertence - está-se na vida (Adorno, 2018) com outros seres e outros humanos. Tal leitura permite a superação de uma visão essencialista e normativa da Vida (aquilo que deve haver, segundo normas e regras, entre o nascimento e a morte) para inscrevê-la na experiência do sujeito como formas de vida.

Para tanto, é necessário compreender que cada sujeito carrega um corpo e por meio deste corpo habita a vida com as experiências e suas subjetividades. Assim, o sujeito está no mundo e junto dele atravessa uma miríade de destinos, que são marcados por (bio)poderes que causam sua miséria: a violência, a fome, a guerra, o capitalismo e suas artérias neoliberais, os flertes ditatoriais e fascistas de governos eleitos democraticamente (ou que tomaram o poder), a burocracia do estado, as mazelas diversas, e toda sorte de forças coletivas esmagadoras que são chamadas de sofrimento social (Kleinman, Das \& Lock, 1997). A violência e o sofrimento social atuam nas subjetividades e nas experiências dos sujeitos, e se inscrevem nas experiências da vida cotidiana de cada um.

Assim, as subjetividades não devem ser entendidas unicamente como sinonímia da natureza humana, mas enquanto caminhos criados pela intersubjetividade da experiência humana, por meio das experiências como fluxos de interação e comunicação interpessoais, como o lugar onde as coisas se dão e acontecem, como os meios em que se amalgamam tanto os processos coletivos como subjetivos, sempre como processos dialéticos, pois

nascemos dentro do fluxo das experiências palpáveis, onde nossos sentidos são primeiramente padronizados pelos símbolos e interações sociais dos nossos mundos locais. Mas nossas subjetividades emergentes também retornam a estes símbolos e interações reconfigurando, repadronizando $e$, às vezes, os reinterpretando completamente. A experiência, então, tem tanto a ver com realidades coletivas quanto traduções e transformações individuais dessas realidades. É sempre simultaneamente social e subjetiva, coletiva e individual ${ }^{5}$ (Kleinman $\&$ Fitz-Henry, 2007, p.53, tradução nossa).

Além disso, as experiências acontecem nos espaços sociais particulares que fazem parte do cotidiano dos sujeitos, como, por exemplo, nas classes sociais em que se reconhecem, em suas formas de expressão de gênero e sexualidade, nos relacionamentos afetivo-sexuais, nas religiões e nas filosofias de vida; de modo que as coisas que realmente importam para os sujeitos ganhem significados morais intrínsecos às suas experiências. Em algumas tentativas de suicídio narradas por interlocutores em Nagafuchi (2017), por exemplo, o término de um relacionamento se apresentou como um momento histórico decisivo para a continuação de suas vidas, porque fazer parte de um relacionamento afetivo, sendo-lhes satisfatório ou não,

4 Como nos casos dos familiares das vítimas do atentado de 11 de setembro, que receberam um valor de indenização que era baseado, entre outras coisas, no salário anual da vítima do atentado, gerando diferenças monetárias nas indenizações recebidas.

5 Original: "We are born into the flow of palpable experience, where our senses are first patterned by the symbols and social interactions of our local worlds. But our emergent subjectivities also return to those symbols and interactions, re-configuring, repatterning, and sometimes even completely reinterpreting them. Experience, then, has as much to do with collective realities as it does with individual translations and transformations of those realities. It is always simultaneously social and subjective, collective and individual." 
era importante não somente para eles mesmos, na esfera individual, como também para suas redes sociais compostas por pessoas em seu entorno.

Para Fischer (2007), as subjetividades estão fundamentadas em quatro registros: (i) o político, que se dá em um sentimento público e moral e, também, nas definições de cidadania de Durkheim, Weber e Marx; (ii) o psicológico, que leva em consideração as individualidades (inteiras ou fraturadas); (iii) o linguístico, do sujeito que enuncia e da gramática da sentença enunciada, até as formulações de sujeito para Freud e Lacan; e (iv) o biológico, do corpo que sente e tem consciência de si, até o nível molecular dos genes e das células. Para ele, são tais registros os responsáveis por formar o terreno no qual alguns antropólogos contemporâneos tratam das subjetividades e dos sofrimentos sociais, e que são continuamente ressignificados em termos das geopolíticas, cadeias de agenciamento e enunciações emotivas que são mais subjetivas que objetivas.

Neste sentido, e.g., Biehl (2005; 2007; 2008) relata a história de Catarina, que fora abandonada pela família como louca em sua juventude e passou o resto da vida em uma instituição psiquiátrica chamada Vita. Catarina carregava em seu corpo uma linguagem própria e um dicionário escrito com as letras da "farmaceuticalização" da saúde mental e do abandono. Em seu corpo inscreviam-se seu gênero, sua condição de saúde e o abandono da própria família. Sua história também fazia inscrever sobre seu corpo, em nível sociopolítico, as políticas de aumento de investimento em medicamentos antipsicóticos de última geração, que vinham na esteira de uma política antimanicomial que não somente não aumentou os recursos para meios efetivos de desinstitucionalização como reduziu os gastos de saúde mental para a metade, em um período de dez anos entre 1995 e 2005. Assim, seu sofrimento também era resultado de escolhas de investimentos de recursos públicos.

$\mathrm{Na}$ antropologia do devir proposta por Biehl (2008) e Biehl \& Locke (2017), articulase uma compreensão pós-foucaultiana do sujeito e de suas experiências afetadas pelo biocapitalismo. Além disso, em suas formulações, Biehl, a partir de Gilles Deleuze, interpreta a sociedade como algo que escapa constantemente, fluindo em linhas de escape pela primazia do desejo sobre o poder, de modo que o sujeito não está-no-mundo somente em decorrência de um processo vertical (como nas ideias de traumas passados de Freud ou das categorias e normalizações de Foucault), porque se considera que a subjetividade

Está no próprio processo do devir, naqueles esforços individuais e coletivos de afrouxar e relativizar, na medida do possível, os marcadores e controles e as violências estruturais, alcançando assim uma imanência, o poder do impessoal - uma vida [...]. Ou seja, podemos estudar a subjetividade como aquilo que excede e escapa, o que não pode ser fixado por uma norma ou numa forma (Biehl, 2008, p. 422, negrito do autor).

A capacidade humana seria plástica neste sentido de se poder modelar o mundo por meio do indivíduo, do social e do material. Este trabalho humano do devir está sempre no limite: "do colapso financeiro, do desmoronamento infraestrutural e da calamidade ambiental; da 
violência racial, do populismo da direita e novos regimes alarmantes de segurança e vigilância; da guerra crônica, migração em massa e disparidades mortais de saúde" (Biehl \& Locke, 2017, p. 4). ${ }^{6}$ Nessa trama, que mais parece uma teia de aranha, as pessoas vão se rearranjando para buscar e construir formas de vida possíveis, e também para se projetarem em algum horizonte ou futuro. Este devir, no sentido de uma plasticidade humana, é também carregado de potenciais destrutivos e violentos. A subjetividade que fundamenta a antropologia do devir leva em conta, pensando nos sujeitos etnográficos, que

\begin{abstract}
seus corpos, os mundos materiais e simbólicos que habitam e as forças estruturais que eles devem navegar crescem para fora de si mesmos, tornando-os outros e imprevisivelmente construtivos e perigosos em seus emaranhamentos e sobre o tempo (Biehl \& Locke, 2017, p. 4, tradução nossa). ${ }^{7}$
\end{abstract}

Neste sentido, o devir é uma proposta que leva em conta a plasticidade e a qualidade de inacabado das pessoas, para formar um horizonte de possibilidades para os sujeitos. A plasticidade e o devir são onipresentes e independem dos cenários de morte e miséria, ao mesmo tempo em que estes processos estão na trama das vidas das pessoas, dando caminho para que possam construir suas próprias trajetórias e imaginar um futuro.

Já para Veena Das, as subjetividades são as experiências de se tornar um sujeito e se dão nas bases da submissão. Por exemplo, na história que ela conta de Asha (Das, 2007), que foi testemunha da violência da Partição na Índia, então enviuvada e posta a articular os complexos laços de parentesco da cultura de castas de seu país, a construção da sua subjetividade, enquanto sujeito com gênero, se dá nas entranhas de sua relação com a violência como um momento originário que penetra o dia-a-dia nos relacionamentos, formando uma atmosfera da qual não se pode sair porque não existe o "lado de fora". Se, por um lado, em sua interpretação da tragédia grega de Antígona, que reconhece seu irmão Polinices como um ser único no mundo e se sacrifica para que ele seja enterrado com os devidos rituais funerários, ${ }^{8}$ e por meio de seu discurso de reconhecimento, Antígona é criada enquanto um sujeito que desafia as leis; por outro, Das percebe na criação da subjetividade de Asha, em sua submissão enquanto sujeito com gênero, o envolvimento de um conhecimento venenoso que se dá nos tentáculos entranhados no cotidiano das violências sofridas, inclusive sexuais, da Partição - com o trabalho diário de reparação de sua condição de viúva e as normas de luto que ela negocia para si e dentro da sociedade de castas da qual ela pertence. A memória do episódio violento não é uma forma de possuir o passado, mas sim constantemente "interposta

6 Original: "of financial collapse, infrastructural breakdown, and environmental calamity; racial violence, right-wing populism, and alarming new regimes of security and surveillance; and chronic warfare, mass migration, and deadly health disparities."

7 Original: "their bodies, the material and symbolic worlds they inhabit, and the structural forces they must navigate all grow out of themselves, becoming other and unpredictably constructive or perilous in their entanglements and over time"

8 Antígona tenta evitar que o corpo de Polinices seja deixado à exibição de todos enquanto apodrece, da forma que fora condenado por Creonte; porque isto faria com que seu espírito vagasse por cem anos no leito do rio que leva até o Reino dos Mortos. 
e mediada pela maneira na qual o mundo está sendo habitado no presente". ${ }^{9}$ (Das, 2007, p. 76, tradução nossa). Ainda,

mesmo quando parece que algumas mulheres tiveram relativa sorte porque escaparam dos danos corporais diretos, a memória corpórea de estar-com-os-outros faz com que o passado cerque o presente como uma atmosfera. Isso é o que quero dizer sobre a importância de encontrar caminhos para falar sobre a experiência de testemunhar: que se o modo de estar-com-outros de alguém foi brutalmente destruído, então o passado entra no presente não necessariamente como uma memória traumática, mas como um conhecimento venenoso (Das, 2007, p. 76, tradução nossa). ${ }^{10}$

Por fim, as formas de vida oferecem um modo potente de fazer as análises dos estudos etnográficos porque elas são parte das sinonímias das experiências humanas no cotidiano. Desde as mulheres vítimas de ataques sexuais em momentos de conflitos históricos na Índia, que sofrem as pressões das consequências ligadas ao gênero e convenções sociais específicas da sociedade indiana (Das, 2007) até os imigrantes que fogem de seus países com regimes ditatoriais, conflitos e guerras civis e tentam chegar até a Inglaterra por meio da França, perambulando em Calais sob o ataque opressivo de tropas francesas (Fassin, 2018). Em particular, em Nagafuchi (2017; 2018), utiliza-se o conceito das formas de vida para interpretar os sofrimentos cotidianos em virtude da violência de gênero ou de sexualidade de pessoas com ideação ou tentativas de suicídio.

Neste artigo busca-se articular a ideia de passado (tensão entre biologia e biografia), presente (como formas de vida) e futuro (como plasticidade ou perda de um futuro imaginado). O suicídio é uma resposta possível, quando se dá a negação destas três ideias. Uma intepretação do suicídio sob esta ótica da biopolítica da vida é em que medida o suicídio deixa de ser somente uma possibilidade e passa a ser uma probabilidade, uma vez que se fundamenta nesta definição de que vidas podem ser continuadas e que vidas devem ser extintas. Quando a plasticidade da experiência humana se anula no discurso, o suicídio se torna uma resposta para a perda de um futuro imaginado.

\section{Morte: "Onde está tua vitória? Onde está teu aguilhão?"11}

Se o devir apresenta uma possibilidade, por meio da plasticidade dos sujeitos, seria

9 Original: "interposed and mediated by the manner in which the world is being presently inhabited"

10 Original: "Even when it appears that some women were relatively lucky because they escaped direct bodily harm, the bodily memory of being-with-others makes that past encircle the present as atmosphere. This is what I mean by the importance of finding ways to speak about the experience of witnessing: that if one's way of beingwith-others was brutally damaged, then the past enters the present not necessarily as traumatic memory but as poisonous knowledge."

11 Na versão do Réquiem Alemão do compositor Johannes Brahms, em que ele usa textos litúrgicos da bíblia traduzida por Martinho Lutero, esta frase (com uma pequena alteração, do alemão "Tod, wo ist dein Stachel? Hölle, wo ist dein Sieg?") aparece em um momento crucial em que se desenha a batalha do homem contra a Morte, em um clímax orquestral onde o homem temente a Deus se pergunta onde estão as armas da Morte. Réquiem, palavra em latim que significa descanso, é uma missa litúrgica geralmente cantada e orquestrada feita para iniciar os processos do luto cristão. Uma das crenças é que o homem morto desafia a morte na volta de Cristo, quando se interrompe o processo do descanso eterno para ascender à vida no paraíso (Ariès, 1981). 
a morte o seu desafio? Busca-se fazer uma pequena reflexão sobre a morte para efetivar a conexão entre as formas de vida e o suicídio, pois parece simplista interpretar a morte ou o suicídio simplesmente como uma quebra na trama espaço-temporal do indivíduo. Assim como a vida, a morte pode ser entendida como fim da vida biológica ou um processo social, mais uma vez evocando a tensão entre natureza e cultura. De modo que, uma vez feito o raciocínio com a vida, como propôs Fassin, é interessante entender como encontrar a morte numa dialética entre a biologia e a biografia.

A antropologia clássica teve particular interesse sobre os rituais mortuários de alguns povos (e.g., Mauss, 2003; Malinowski, 2004). ${ }^{12}$ Porém, é na antropologia contemporânea e na história que encontramos uma discussão sobre a morte que diz respeito à tensão entre natureza e cultura.

Ariès (1981) mostrou como o conceito de morte foi entendido durante a história no Ocidente (dos anos 1000 até a atualidade). De uma morte domada, na qual o indivíduo que morria tinha controle dos rituais e se despedia da comunidade em seu leito, até a morte moderna, invisível, em um leito hospitalar, o que só é possível em decorrência dos conhecimentos e tecnologias que prorrogam a chegada do momento final; as variações são sempre transformadas segundo os temas individuais, da luta da sociedade contra a morte, das crenças em torno do que ocorre no pós-morte e na crença na existência de um Mal maior, responsável por causar a morte. Deste modo, a morte sempre foi um evento social, dirigido e determinado pelos poderes que em cada momento histórico exerceram maior ou menor influência (e.g., Igreja Católica, Estado, Ciência, etc).

É importante ressaltar que, no contemporâneo, a morte vem se tornando novamente um evento público, seja em razão das narrativas biográficas das mortes de pessoas famosas (Rondelli e Herschmann, 2000), seja pela transmissão em tempo real, na Internet, de cenas de morte e, até, de suicídio, como em caso relatado na pesquisa Nagafuchi (2017), de um jovem que combinou em um fórum a transmissão de sua própria tentativa de suicídio. Ainda, é possível encontrar cenas de morte em diversos vídeos de sites como YouTube.

Assim, no momento, há um contraste entre a morte invisível, que ocorre em leitos hospitalares, e em que as decisões são feitas aparte dos familiares pelos profissionais de saúde, como médicos e enfermeiros, em constante gestão da técnica e de emoções (Silva e Menezes, 2015); e a morte exposta e espetacularizada, seja por cenas de suicídio imbricadas no ambiente urbano das cidades (Marquetti, 2012) ou nas redes sociais e Internet (Nagafuchi, 2017; Nagafuchi e Adorno, 2016).

A definição de morte também articula certas disputas de poder. Por exemplo, houve, em certo momento de nossa história recente, a necessidade de se pensar uma definição do fim da vida, por meio da "morte encefálica" ou "morte cerebral" (Lock, 2002; Agamben, 2012). Tal definição se fundamentava num imperativo de, primeiramente, evitar erros médicos que poderiam resultar na possibilidade de enterrar pessoas ainda não mortas e, então, criar normas

12 Mauss e Malinowski estavam interessados na descrição de processos e rituais de povos melanésios e aborígenes australianos. A morte, para estes povos, é um ente social e obedece aos resultados de magias ou possessões por espíritos de animais, por exemplo: "A morte e a vida mantêm-se na balança entre a eficácia das palavras a natureza dos feiticeiros e de espíritos protetores, que são coletivos para os povos" (Nagafuchi, 2017, p. 107). 
procedimentais para a realização de transplante de órgãos entre corpos. Na ocasião, diversos especialistas da medicina de diferentes áreas pensaram sobre e articularam a definição de morte para declarar a existência de um momento entre estar vivo e morto - que só é possível a partir dos desenvolvimentos tecnológicos e científicos -; até chegarem num acordo. $O$ estado da "morte cerebral" é irreversível, portanto, um indivíduo com funções vitais mantidas por aparelhos externos ao corpo, porém sem atividades encefálicas, avaliadas com protocolos específicos, tendo condições, é capaz de doar seus órgãos para outros indivíduos que estão acometidos por doenças graves e necessitam destes órgãos para continuarem vivos.

Este exemplo é essencial para entender a morte, na tensão entre biologia e biografia, porque envolve uma articulação de moralidades, tanto em um sentido macrossocial como em nível microssocial: se, por um lado, a definição de morte exigiu um consenso de diversos especialistas, por outro, a doação de órgãos depende de um encadeamento de valores locais sobre uma decisão familiar em torno da possibilidade de doar ou não os órgãos daquele que falece.

\section{A fantasmagoria do suicídio}

O suicídio sempre deixa fantasmas. No Império Romano, em alguns lugares, a mão de quem cometera suicídio, a utilizando para tal, era enterrada em local separado do corpo, para evitar que o morto retornasse e atentasse contra os vivos. Na Idade Média, os espíritos dos que se afogavam intencionalmente podiam avançar de dentro dos rios para pegar os pés de quem passasse perto do local (Minois, 1999). Já na China, os espíritos das noivas vermelhas - cor usual para as mulheres que casam, no país -, abandonadas pelos maridos, os assombrariam para o resto de suas vidas (Marquetti, 2018).

Ao longo da História do Ocidente, o suicídio contou com distintos modos de entendimento. Algumas escolas do pensamento grego consideravam que a morte voluntária fazia parte da liberdade de escolhas individuais, outras, e.g., os pitagóricos, a proibiam, por acharem que ela profanava o corpo e quebrava a harmonia das relações numéricas que regulavam o mundo e a alma. Na Idade Média, o suicídio poderia ser considerado como um ato de heroísmo das elites religiosas e da nobreza, ou ser enfaticamente condenado, caso fosse praticado por um camponês. A condenação não vinha somente nas formas de expor ou destruir os cadáveres, arrastando-os ou pendurando-os de ponta-cabeça na frente de todos, como também por meio dos confiscos, pelo estado, dos bens dos familiares sobreviventes, o que era previsto no Direito Romano. O Cristianismo exercia forte influência sobre a compreensão do suicídio, tolerando atos de martírio e autoflagelação; até Santo Agostinho considerar o ato equiparável ao homicídio, pois quebrava o mandamento "não matarás". Como a Igreja Católica jamais conseguiu ter controle sobre o ato, não lhe restou outra opção a não ser caracterizar o suicídio como sinistro e diabólico. (Minois, 1999; Guillon \& Le Bonniec, 1990).

No final do século XIX, o suicídio começou a ser tratado como doença, embora para o senso comum permanecesse como resultado de ação direta do Diabo. Mais adiante, Durkheim 
deu visibilidade e incluiu o tema em sua proposta de Sociologia; Sigmund Freud encontrou a razão em forças destrutivas que integravam o interior do indivíduo; Jean Baechlar atribuía ao psicológico e à genética as causas da morte voluntária. Para Minois (1999), mais do que visões estanques, as explicações se completariam. Há, no contemporâneo, o debate sobre a liberdade de escolha dos indivíduos por meio da eutanásia ou do suicídio assistido em casos de doenças terminais, que acarretam grande sofrimento.

O suicídio sempre teve um caráter fantasmagórico na nossa história ocidental, por ser invisivel e onipresente, que carrega ou é presságio do Mal. Os poderes institucionais, seja o Direito Romano, a Igreja Católica ou a Medicina, se impuseram na responsabilidade de dar a palavra final, geralmente atribuindo a causa a razões que dizem respeito ao indivíduo. Contudo, Durkheim (2008) e Marx (2006) inscreveram seu entendimento na sociedade.

Enquanto evento registrado no tempo social, o suicídio é a "transgressão da morte interdita" (Marquetti, 2014, p. 238), porque representa a quebra das regras da dicotomia público/ privado e, também, as "rígidas prescrições do lugar da morte na sociedade atual" (Marquetti, 2014, p. 238). As cenas e os roteiros da morte voluntária destroem e reconstroem "os limites entre o público e o privado, num processo de comunicação de novos sentidos de vida, cotidiano e sociabilidade" e, ainda, "as fronteiras entre tais espaços e usos estão em remodelação constante, seria o suicídio uma das formas culturais de indagar, romper e engendrar novas linhas divisórias entre público e privado? Ao que parece, sim" (Marquetti, 2014, p. 244).

É deste modo que o suicídio deixa de ser somente um item nosográfico e causa mortis marginal e entra de vez para a cultura e o social, pois se situa sobre o fundamento da relação do ser humano com a morte. Staples \& Widger (2012) sugerem que o tema da morte voluntária atinge a todos e que as questões levantadas desafiam o entendimento, não só da natureza humana (biologia) como também de sua cultura (biografia), já que é uma negação, ao mesmo tempo, das duas coisas. Além disso, eles consideram que, como os questionamentos sobre a existência e a sobrevivência são cruciais, então o suicídio deve encontrar-se no centro das indagações antropológicas. O suicídio é, ao mesmo tempo, um ato destrutivo, por interromper a vida, e um ato constitutivo, pois possibilita uma compreensão do mundo e da experiência humana.

\section{Parte 2 - sujeitos etnográficos: Antônio e Tomás ${ }^{13}$}

Em pesquisa anterior, interlocutores de uma etnografia digital foram encontrados por meio de um questionário online ${ }^{14}$ divulgado em redes sociais e, também, em variados sites

13 Nomes fictícios. Na pesquisa, além de escolher outros nomes para os interlocutores, misturei dados biográficos para preservar ao máximo suas condições de anonimato.

14 O questionário online possuía poucas perguntas sobre ideação e tentativa de suicídio, foi divulgado em redes sociais e ficou disponível durante duas semanas. No total, 1.139 pessoas responderam à pesquisa. No final do questionário deixei um espaço para quem quisesse contribuir com a pesquisa, deixando dados de contato pessoal. Dentre todas as pessoas foram selecionadas 4 para compor parte da etnografia. Para além delas, a etnografia digital contou com informações de sites e interações em fóruns da Internet. Para mais informações sobre a metodologia, cf. Nagafuchi (2017) e para mais informações sobre o questionário online, cf. Nagafuchi (2018). 
e fóruns e em incursões à deep web, que é a Internet não indexada por buscadores como Google ou Yahoo (Nagafuchi, 2017). Nesta pesquisa, o objetivo era entender como as relações das categorias de gênero e de sexualidade se apresentam nos discursos de suicídio dos sujeitos pelo prisma do sofrimento social.

A seguir são apresentados relatos biográficos de dois participantes da pesquisa. As semelhanças entre os dois se encerram no mesmo estado de nascimento: ambos nasceram em um estado do sudeste. Antônio, à época, tinha 43 anos e Tomás, 25. A escolha dos dois foi efetuada a partir das diferenças em seus discursos; depois é apresentada uma análise segundo a perspectiva teórica exposta na primeira parte do artigo.

\section{Antônio}

Antônio conta com ternura as lembranças de sua infância e até revela, com humor, não ter sido um filho planejado. Os pais trabalhavam em fábricas da região e faziam bicos para seu sustento e da irmã quatro anos mais velha. Aos 14 foi tirado da escola para ajudar nas contas de casa, porém retornou no ano seguinte, por não ter conseguido emprego. Aos dezoito anos começou a vender pastel na feira e permaneceu neste trabalho por cinco anos. Neste tempo, os pais se separaram e sua irmã e mãe começaram a frequentar os cultos de uma igreja evangélica - "a pior coisa que aconteceu em nossas vidas, diga-se de passagem"15 - e se mudaram de casa. Ele então decidiu cuidar do pai, que acabara de ter recebido o diagnóstico de insuficiência renal crônica, e teve uma depressão. Eles permaneceram juntos até sua morte.

Antônio fez curso superior de Serviço Social e se tornou mestre na mesma área. Ele reclamava constantemente sobre o equilíbrio emocional exigido pelo trabalho, em decorrência do contato com populações em vulnerabilidade extrema. Duas de suas tentativas de suicídio narradas ocorreram após episódios traumáticos no trabalho, em épocas de muita chuva na região serrana do Estado: em uma delas, uma retroescavadeira que buscava sobreviventes de um soterramento, ao cavar o barro, dividiu o corpo de uma criança em duas partes, na frente do pai, de Antônio e de outras pessoas que acompanhavam a busca. A solidão estava presente, em menor ou maior medida, nas histórias de praticamente todos os interlocutores da pesquisa, como um sentimento praticamente sem solução, sem possibilidade de mudança no futuro. Antônio disse diversas vezes que seu maior sonho sempre foi casar e ter uma casa com muitos filhos. Contudo, ele alegava jamais ter se sentido desejado, pois achava que estava acima do peso, mesmo quando conseguiu perder 30 quilos depois de uma dieta (comia uma maçã por dia). Suas parcerias afetivo-sexuais sempre foram erráticas, quando aconteciam. Entre os 22 anos, quando teve a primeira relação sexual, e os 27 anos teve dois namorados. Ambos os relacionamentos foram mantidos em segredo; o primeiro porque o parceiro era casado com uma mulher e o segundo porque o parceiro tinha medo da opinião dos amigos. Até que um dia Antônio conheceu Felipe no caminho para uma festa.

Felipe e Antônio viveram juntos por 8 anos, período que ele dizia terem sido "felizes

15 Nas biografias, as frases entre aspas são atribuídas aos interlocutores e estão registradas em diário de campo. 
para sempre". Contudo, nesta época foi diagnosticado com sífilis, e descobriu que Felipe o traía. O parceiro dependia da ajuda financeira de Antônio, que emprestava seu cartão de crédito. Assim, descobriu que Felipe estava gastando seu dinheiro com garotos de programa. Antônio sempre perdoava, não tocava no assunto e se desviava, ficando até tarde na rua bebendo, para evitar confrontos.

A partir de então, a relação afetiva se transformou naquilo que Giddens (1993) chama de relacionamento puro, que se mantem enquanto ambas as partes percebem alguma vantagem nesta manutenção. Existia uma combinação, enquanto Felipe terminava o doutorado: Antônio ficaria responsável pelas contas de casa; o contrário aconteceria depois, quando Antônio estivesse no fim do mestrado. No entanto, na hora de Felipe cumprir o combinado algumas coisas aconteceram: ele manifestou desejo de prestar concurso para professor em outros estados e o pai de Antônio faleceu. Felipe pediu que Antônio saísse do apartamento o mais rápido possível - um pedido de separação. Não houve acordo, Felipe saiu de casa, se hospedou em um amigo que morava no mesmo prédio e os outros amigos o teriam abandonado. Nenhum quis ser testemunha em uma ação judicial requerendo parte dos bens adquiridos em conjunto pelo casal. Com todos os acontecimentos, Antônio perdeu o prazo para entregar a dissertação, razão pela qual também perdeu um emprego de docente em uma universidade.

No final daquele ano, às vésperas das festas de final de ano, ainda na casa do amigo, Antônio viu Felipe com seu novo companheiro, no elevador. Tentou cortar seus pulsos e as pernas com uma garrafa de cerveja quebrada. Alguns amigos o socorreram e não o levaram para o hospital. Alguns dias depois, o namorado do amigo que o hospedava pediu que ele abandonasse o apartamento porque "ninguém confia em suicidas". Ficou alguns dias dormindo na rua e foi levado para o interior do estado por amigas.

A partir de então Antônio conta que teria tentado se matar ainda sete vezes, depois do término do relacionamento. As tentativas foram se aperfeiçoando cada vez mais, com mistura de medicamentos para depressão e bebidas alcoólicas. Foi internado algumas vezes, foi estigmatizado como suicida e perdeu alguns empregos e oportunidades. No entrementes, a irmã o denunciou ao Ministério Público por negligenciar cuidados à mãe e Antônio contou que ela ligava para os seus chefes, pedindo que ele fosse demitido.

\section{Tomás}

Tomás se esforça para mostrar seu lado intelectual. Em sua fala, utiliza certos conceitos e expressões, como "sensibilização da matéria", "sensação castradora de estar vivo", "vida nua" e outras que revelam tratar-se de pessoa letrada em conhecimentos de diversos autores, como Heidegger, Freud e Agamben. Ele indica que quem estuda suicídio deve ler Durkheim e Camus. Mas nada disso parecia mais desafiador que a sua vontade de morrer, que é essencialmente existencial: ele demonstra apego ao desejo de não existir, de voltar a ser matéria não viva. $O$ desafio, no caso, era que para ele a vontade de uma não-existência era levada ao limite, porque ela, 
Presente em maior ou menor medida em cada caso de suicídio, atinge seu ponto limitrofe na possibilidade de uma linguagem da morte porque, na leitura desta linguagem, a vontade de não existir parece incontornável; mesmo que ela seja sumariamente ignorada na maior parte dos textos sobre suicídio fora do problema [filosófico] da existência (Nagafuchi, 2017, p. 180).

Ele parece querer evitar falar de detalhes pessoais e biográficos, mas aos poucos revelase, entre suas elucubrações teórico-filosóficas sobre a vida e a morte. Nascido de uma família com boa condição financeira, cursou letras na universidade federal do estado e fez mestrado na mesma instituição. Foi para o Japão estudar a língua japonesa e depois se mudou para a Alemanha. Da última vez em que nos falamos, ele estava tentando um processo seletivo para fazer doutorado em uma universidade alemã.

Sua inquietação maior com a vida é sobressaltadamente existencial ou, ainda, existencialista. Estar vivo, para ele, nada mais é do que um cumprimento exaustivo dos 'rituais humanos' no cotidiano, que faz parte, no final das contas, de um teatro. Sua vontade de não viver não é necessariamente uma vontade em direção à morte, mas em direção à extinção completa do ser, como uma fuga da obrigação de fazer parte dos rituais, da qual não houve escolha possível. A vida para ele é uma sensibilização da matéria que foi tomando proporções gigantescas, uma passagem da matéria não-viva para viva, de modo que ele preferia fazer parte da matéria não-viva, insensivel e inerte, não num sentido de nunca ter feito esse movimento, mas como um retorno à 'imanência das coisas' (Nagafuchi 2017, p. 181).

No fim das contas, nada disso passava de um jogo ou de uma atuação em um mundo de rituais que não fazia sentido. Ele também não se via fazendo parte do "mundo do trabalho", aquele com roupas formais, deadlines e escritórios, uma vez que isso o faria participar fatalmente desta ficção. No momento de sua vida em que conversávamos, ele disse ter um companheiro, que às vezes o chamava de "namorado" - embora não se considerasse monogâmico. 0 parceiro ficava responsável por todas as coisas burocráticas do cotidiano, como fazer comida, lavar roupa, tirar o lixo; e Tomás via o relacionamento afetivo como uma troca de favores, "forneço minha companhia e reviro a alma dele com meu olhar pouco ortodoxo sobre as coisas; em troca, ele me ocupa das coisas do mundo e me livra delas".

Tomás diz que o corpo é como uma casca que não tem qualquer relação com seu interior - culturas, hábitos e costumes seriam inscrições sobre o próprio corpo. Sua única necessidade é o sexo e o resto poderia ser resolvido apenas com o cérebro. Ele precisa do corpo para conseguir sexo e o faz, por vezes, de forma compulsiva, várias vezes ao dia. O sexo seria uma forma "primitiva" de se conectar à sociedade, sem necessariamente fazer parte do teatro humano. É o que o faz se sentir vivo.

Ele é um jovem de corpo atlético, confessa que pratica esportes duas horas por dia. Ele tem a necessidade de que seu corpo seja atraente, para realizar sua pulsão sexual numa 
espécie de economia que se baseia nas trocas que seu corpo pode empreender com outros corpos - como tudo isso não passaria de um teatro, o outro se torna apenas um corpo. Mesmo tendo um parceiro, ele o considera como um "resolvedor" das pendências diárias da vida e não deixa claro em que medida o deixa fazer parte de sua própria vida, uma vez que ele considera o romance como um dos rituais que despreza e, portanto, não o entende.

\section{Parte 3 - discursos de suicídio; passado, presente e futuro}

Estas duas histórias podem ser consideradas arquetípicas, pelos discursos apresentados. Variações dos mesmos temas apareceram nas falas de outros sujeitos da pesquisa. Foram aqui utilizadas para mostrar dois tipos de discursos, diferentes em conteúdo e forma, mas que podem ser extremos de uma mesma linha. Por um lado, o discurso indica uma forte tentativa de fazer parte de vida; por outro, há um niilismo que nega não a Vida, mas as formas de vida possíveis. É importante salientar, no entanto, que o que emerge das narrativas de sofrimento de suas biografias são temas inerentes às agências de orientações afetivo-sexuais, que eram tema central da pesquisa da qual foram retiradas. Por outro lado, como será apresentado a seguir, as narrativas fazem parte de um complexo cenário, no qual são identificadas características comuns em sujeitos de outra pesquisa etnográfica (Widger, 2012), o que indica a possibilidade de um desenvolvimento na produção de conhecimento sobre o suicídio, que merece ser mais explorado.

Antônio busca fazer parte da vida, por intermédio de um relacionamento afetivosexual. Este tema esteve sempre presente em nossas conversas, e a não existência de um parceiro o deixava numa espécie de solidão sem solução. Tomás não acredita fazer parte da vida, porém não lhe resta outra opção senão estar na vida. Ele confessou que sabe exatamente o que fazer, que sabia o melhor método (para ele, o mais indolor) para cometer o suicídio, que era exatamente o mesmo método que alguns fóruns da deep web se dedicavam em descrever como o mais aconselhado (cf. Nagafuchi, 2017).

A diferença desses discursos evidencia que o olhar para o fenômeno do suicídio não pode ser unívoco, de único caminho de ida, ele deve estar aberto para todas as vicissitudes e idiossincrasias de que são capazes os seres humanos. Buscar entender um suicídio é como olhar para um fractal: não importa o quanto nos aproximamos da imagem, sempre veremos a mesma estrutura: mais que entender a imagem, é necessário compreender a estrutura e o que é responsável por formá-la.

Estas histórias de suicídio explicitam que distintos aspectos das subjetividades humanas estão presentes no cotidiano de cada pessoa. De certo modo, elas buscam conduzir o olhar para algumas tipologias (ou arquétipos), presentes em seus discursos sobre vida e morte. Nos discursos e nas biografias dos sujeitos mencionados em Nagafuchi (2017), ressaltam-se, por exemplo, o desejo sexual como locus da culpa, o desejo proibido; o olhar para o próprio corpo como socialmente desajustado, por estar acima do peso considerado "ideal" ou "correto" pela sociedade; e também no nilismo, que é a base de uma angústia existencial que faz parte da 
vida perder o sentido. Todas as histórias são atravessadas pela dor e angústia da solidão. Tais sofrimentos fazem o mundo entrar em processo de aniquilação, transformando a forma de vida em algo sem forma e sem vida.

A partir de alguns aspectos em comum, é possível traçar arquétipos nestes discursos de suicídio, criando categorias que não são mutuamente exclusivas nem têm ou deveriam ter um apelo de categorias duras, no sentido de que o todo não pode ser dividido em tais categorias. Solomon (2014), por exemplo, enumera quatro tipos de discurso: o suicídio como ato impulsivo, praticado sem muita ou nenhuma reflexão sobre suas consequências; a consideração do ato como vingança, como se o suicídio não fosse irreversível; aquele da lógica falha, em que há ideação e planos para atingir o objetivo; e aquele da lógica racional, em que o sujeito, após pesar todas as possibilidades da vida, preserva no discurso a crença de que os momentos de prazer não superariam os momentos de sofrimento. Widger (2012), em etnografia sobre suicídio no Sri Lanka, enumera os seguintes discursos: do sofrimento, como inabilidade de alterar a tristeza e a falta de esperança; da frustração, como incapacidade de alterações na vida afetiva, nos modos de ocupação do tempo e nas finanças; da raiva, como a ativação por consequência de um episódio cotidiano, que guarda semelhanças com o discurso impulsivo, pois vem sem aviso ou planejamento. Como as histórias de suicídio são complexas, podem envolver agenciamentos de diferentes arquétipos. Além disso, há prevalência de certos aspectos específicos, quando são feitos recortes de categorias associadas aos marcadores sociais, como gênero, classe e idade.

Antônio, por exemplo, ao contar sua história, revela que suas tentativas ocorreram após determinados episódios em sua vida, como eventos no trabalho ou o término de um relacionamento afetivo. Deste modo, seu discurso estaria próximo do impulsivo ou da raiva. Contudo, como revelou nas últimas conversas, ele não se vê capaz de realizar um dos grandes sonhos da vida, que é constituir família e ter filhos; dado que aproximaria seu discurso da frustração. Por outro lado, Tomás, com a retórica do niilismo e da falta de sentido desta vida, teria um discurso mais próximo da lógica racional, efetuando conclusões a partir de argumentações filosóficas.

Os arquétipos são modelos explicativos que possibilitam um entendimento do sentido oculto por trás do discurso, porém eles não têm a mesma capacidade heurística quando olhamos para as ações tomadas. Tal afirmativa se baseia na fundamentação do discurso na linguagem, de modo que nem sempre há uma ligação direta com as ações. Por exemplo, os métodos escolhidos: pode-se suspeitar que alguém que escolhe saltar da janela de um apartamento faça por impulso, mas na maioria dos casos é impossível saber se houve planejamento ou pensamento racional antes do salto. Assim, os arquétipos podem explicar os discursos, mas há um conjunto de meandros em um ato em direção à morte voluntária que demanda outros tipos de análise ou compreensão.

Outro interlocutor da etnografia em Nagafuchi (2017), Domingos, disse certa vez que estava disposto a encontrar uma arma de fogo para cometer o suicídio. Ele já havia tentado se cortar, comprou uma corda e tentou se enforcar, dirigiu embriagado e em alta velocidade para chocar-se com uma árvore ou um poste, mas nenhum destes métodos garantiam a certeza 
de morte e ausência de sofrimento, pois poderiam ter consequências dolorosas. Contudo, ele intuía que uma pistola poderia causar sua morte, e que a rapidez do desfecho contaria com menos sofrimento. Em resumo, tentou comprar de forma ilegal, inclusive pedindo auxílio para um amigo policial, mas não conseguiu. Há uma série de características neste caso, desde os valores que regem a visão da própria morte (rápida e indolor) até a dificuldade de se conseguir uma arma de fogo num país que, naquele momento, apresentava regras rígidas para o porte de armas.

Tais dados indicam o quanto o suicídio é um ente social e cultural da experiência humana. Tanto os discursos quanto as ações estão em constante negociação entre mundos e subjetividades locais e globais, neste grande fractal que é o enquadramento do fenômeno. Há um caminho de ida, em que as ciências humanas ajudam a compreender um fenômeno complexo, mas também há um caminho de volta, pois tal entendimento do suicídio ajuda a vislumbrar o que é esta parte da Vida em que se inscreve a experiência humana.

\section{Parte 4 - lugares etnográficos: navegando em mares de discurso}

A etnografia em ambiente digital permitiu contato com diferentes discursos. Há fóruns e sites dedicados à discussão do suicídio com os mais diferentes vieses. Alguns exemplos: um fórum numa rede social em que as pessoas podem postar suas cartas de despedida (hipotéticas ou não), um fórum na mesma rede em que o suicídio é "sancionado", no qual os participantes conversam abertamente sobre suas vontades e tentativas, com a proibição de julgamentos ou preconceitos. O fórum não é "pró-suicídio", no sentido de incentivar que as pessoas se matem, mas "pró-escolha", de modo que os temas são fundamentados no vislumbre da possibilidade real da morte voluntária; um braço deste fórum na deep web, em que os participantes podem discutir os métodos, e comprar ou vender "kits suicídio"; outro fórum na deep web, em que as pessoas procuram anestésicos veterinários e parceiros ${ }^{16}$ para o ato; um site de uma antiga seita que prega o suicídio para uma "limpeza" do planeta terra, porque os seres humanos estariam colaborando para sua destruição.

Estas plataformas têm ligação com um fórum dos primórdios da internet 1.0 que era chamado de "Alt-Suicide-Holiday", mais conhecido como ASH, que surgiu devido à curiosidade de algumas pessoas em torno da ocorrência de muitos suicídios em feriados (justificativa do "Holiday"; já o "Alt" vem de "alternative", pois seria um espaço para discussões para além do que poderia ser considerado normal, normalizado ou normatizado). Depois de muitos anos de atividade, diversos membros teriam dissipado para outras plataformas, conforme a internet passava por mudanças consideráveis. Uma das frequentadoras fundou a Igreja da Eutanásia, que é a seita referida. Sem detalhar a história ${ }^{17}$, os membros da seita criaram um material que

16 A prática de procurar parceiros de suicídio na internet é mais frequente no Japão. Para Ozawa-de Silva (2008: 2010), há uma conexão entre as subjetividades e a questão cultural da solidão crônica dos habitantes do país. Três jovens japonesas se conheceram pela internet e, ao se suicidarem, formaram com os corpos o ideograma japonês para a palavra "rio", (川)

17 A Igreja da Eutanásia não tem mais atividade, embora ainda seja possível acessar o site. Para uma história mais detalhada, cf. Nagafuchi (2017). 
hoje é amplamente compartilhado na Internet não indexada.

O material é um manual do suicídio, uma espécie do "modo de usar" de Guillon \& Le Bonniec (1990) contemporâneo. ${ }^{18}$ No documento há uma construção do que seria o método mais eficaz e "limpo", a partir do pressuposto de que um ato suicida deve ser cercado de determinados valores e moralidades: o método deve ser rápido, para não causar angústia e sofrimento; deve ser o mais indolor possivel; deve ser garantido, porque há riscos de institucionalização caso sobreviva; deve ser discreto, para que ninguém descubra as intenções; deve ser seguro, principalmente para não causar danos físicos em outras pessoas; deve ser acessivel, com uso de materiais de fácil acesso; e deve ser limpo, para que ninguém precise limpar a sujeira depois. Além disso, o manual classifica a razão de desaconselhar alguns métodos, de acordo com os valores apresentados, e.g., o enforcamento não é rápido nem garantido, o salto de lugares altos e o gás de cozinha são perigosos para outras pessoas, o afogamento não é discreto e assim por diante. A partir desta reflexão, os autores escolhem aquele que seria o melhor método.

O material estava disponível no site da Igreja da Eutanásia, até que alguém que cometeu suicídio foi encontrado com o manual, o que resultou em demandas jurídicas para sua retirada. No entanto, ainda é possível encontrá-lo, pois circula em alguns fóruns específicos sobre suicídio na deep web. Ele também está numa espécie de Wikipedia da Internet profunda. O método elencado pelo material é amplamente discutido nestes fóruns, com posts de ajuda sobre como e onde encontrar materiais, ou como comprar um "kit" com todos os itens necessários. Há um modelo de cálculo no qual é possível determinar as quantidades ideais e o tempo necessário, de acordo com o peso da pessoa. Tomás, por exemplo, tinha tais informações, porém nunca revelou onde as encontrou.

Os discursos nestes fóruns versam em torno da incompatibilidade com o mundo contemporâneo, os sujeitos que lá escrevem geralmente apontam argumentos semelhantes aos de Tomás, de que o sofrimento provável não compensaria os possíveis momentos agradáveis. Este sofrimento é um tipo de angústia existencial, na qual nada faz sentido e nada seria capaz de fazer entender a vida como algo que vale a pena. Aleksis, por exemplo, tem um discurso que aponta diversas destas características:

Eu quero morrer. Já faz tempo. [...]. Suicídio é uma decisão que eu deliberei cuidadosamente após analisar todas as alternativas ou falta de outras opções. Eu não tenho escolha a não ser pensar que sou incapaz de uma vida humana. Eu não sinto orgulho ou reconhecimento ou satisfação ou qualquer tipo de sentimento positivo. Todas as minhas emoções prazerosas têm a ver com alívio negativo, a depravação de esconder a verdade, das consequências evitadas e da autonegação. [...]. Sou categoricamente uma falha moral. Em resumo, não tem um 'eu' para matar - somente um corpo e uma coleção de impulsos e caprichos. Eu duvido fortemente que alguém possa me ajudar. Sou

18 O livro de Claude Guillon e Yves Le Bonniec, "Suicídio: modo de usar" oferece uma lista de diversos métodos, com considerações, recomendações e técnicas. Lançado originalmente na França, o livro foi proibido no país e originou uma lei local que condenava o incentivo ao suicídio. No Brasil, o código penal prevê intepretação semelhante. 
triste, medroso, solitário; mas tudo seria tolerável se eu tivesse a mínima evidência que eu pudesse viver com integridade, me realizar e ser feliz. Eu sou suicida desde os 9 anos [...]. Eu só tentei uma vez, mais ou menos 8 anos atrás [...]. ASH me ajudou muito com a minha tentativa - não com os detalhes práticos do suicídio, já que os melhores métodos me eram escondidos, mas com a preparação psicológica. Eu estava pronto para morrer. Eu me sentia mais convicto e lúcido como nunca. Eu entendia completamente o que eu estava fazendo. A humilhação do resultado, estar hospitalizado e consciente, era insuportável, o que tem sido um dos maiores impedimentos de tentar novamente. As instituições são feitas para lidar com pessoas mentalmente instáveis, não com pessoas decididas que chegaram à conclusão que as 'autoridades' jamais sonhariam em entender suas determinações. [...]. Eu quase me esqueço, em fantasia, que os outros não entendem a vida que eu quero ter ou porque eu prefiro encarar a morte do que meramente sobreviver. Eu quero morrer porque eu penso que a única forma de viver é tendo prazer absoluto em aperfeiçoamentos pessoais, produtividade $e$ relacionamentos com valores igualitários - e eu tenho provado a mim mesmo constantemente que eu não sou capaz dessas coisas. Eu sou, franca e emocionalmente, sub-humano. E embora eu tenha prazer absoluto nos relacionamentos com as pessoas à minha volta - apesar do meu tom aqui, eu sou uma pessoa relativamente agradável - nenhum deles traz o tipo de proximidade que eu anseio, o tipo de proximidade que nem ao menos é possível com um arruinado e falido feito eu. Eu preciso me privar dos meus desejos se eu estiver preparado para morrer. Eu não acho que 'tem uma parte de mim que queria viver' [...]. Eu não acredito na minha coragem - eu confio na minha mente. Ela toma as decisões e o resto de mim tem que se virar. Vai ser um longo processo, [...], mas eu ternamente estimaria qualquer conselho (Nagafuchi, 2017, p.40-1).

Apesar de algumas semelhanças com o discurso de Tomás (ser incapaz de uma vida humana, há somente um corpo e uma coleção de caprichos, etc), o sofrimento existencial de Aleksis o leva a crer que ele é menor que um humano, algo que não conseguiu participar da vida porque se considera uma falha moral, ou falido, incapaz, triste, medroso e solitário. Ele entende que as formas de vida que sobraram para existir e ser-no-mundo não compensam a tentativa de continuar sendo. Ele não se vê como mentalmente instável e acredita que institucionalizações que poderiam acontecer após uma tentativa que não teve o resultado esperado só aumentariam seu sofrimento.

\section{Parte final, ou melhor, remate - a perda de um futuro imaginado}

A antropologia do devir e os antropólogos que estudam a violência, o sofrimento e as subjetividades consideram a existência de um poder da plasticidade dos sujeitos que requerem estar-na-vida com as formas de vida que conhecem e exercem suas existências no cotidiano. Afinal, são milhões de pessoas que estão nos contextos mais tenebrosos, seja na pobreza extrema, seja em contextos de guerra ou de desastres naturais; há que se dar um jeito de 
continuar vivo. O suicídio, independentemente do tipo de discurso em que se sustenta, pode ser interpretado como ausência do devir ou, ainda, como devir em sua forma extrema. É a desconexão definitiva da vida. É, portanto, uma incapacidade da plasticidade ou a plasticidade em sua forma mais radical - a destruição das formas; é a negação da vida; é a aniquilação do próprio mundo. Portanto, é a perda de um futuro imaginado.

A imagem da perda de um futuro imaginado parece eficiente para compreender o fenômeno do suicídio. Evidente que perder o futuro imaginado não implica em pensamentos e práticas suicidas, assim como o ato de tentativa do suicídio não é a negação total de um horizonte no qual se desenha o futuro. A potência explicativa reside no termo "imaginado", uma vez que o cenário desenhado em uma imaginação toma residência nas subjetividades. $O$ futuro imaginado é a porção que o sujeito destina à sua individualidade para estabelecer relação com os outros e, portanto, com a coletividade. É um amálgama entre o passado, o presente e o futuro; é o modo como o sujeito articula o próprio corpo com sua biografia, com suas formas de vida e suas possibilidades de estar-na-vida, por meio das plasticidades que escolhe para continuar na linha espaço-temporal que o manterá na vida. Perder o futuro imaginado é um modo simbólico de morrer e, portanto, o suicídio é um vislumbre de quem o perde.

Ainda, é possível interpretar o futuro imaginado como um conjunto de possibilidades das formas de vida. Para Antônio, as formas de vida que imagina para si envolvem o pertencimento a uma família homoconjugal e homoparental, e com as perspectivas desta experiência: o convívio cotidiano, os cuidados com as crianças, as negociações que mantêm o relacionamento e assim por diante, ainda que nos moldes da boa aparência das famílias de filmes e das famílias dos outros. O primeiro passo para estar em tal família é ter um companheiro afetivo, o que para ele não acontece porque, por exemplo, ele se considera fora dos padrões estéticos dos corpos desejados, e fora de uma faixa etária adequada, a negação de seus desejos não o permite entrar e estar neste mundo. Tomás não se vê dentro das formas de vida a que tem acesso, porque acredita que entrar para as formas de vida que conhece o sancionaria enquanto um ator que interpreta o teatro da humanidade; se não há motivo nem vontade de fazer parte, tais formas de vida deixam de ter vida e ficam como formas que flutuam no mundo. Então, o mundo, para ambos, se desfaz, se quebra, se despedaça, espelhando os pedaços de suas subjetividades que buscam reconstruir, o que não deixa de ser, de certa forma, um jeito de experimentar a existência. Sem formas de vida no horizonte, não há possibilidade para futuros imaginados.

Segundo o discurso de Aleksis, ele entende que falhou ao buscar formas de vida legítimas e não vê possibilidades de reverter a solução encontrada no suicídio. É um discurso de angústia existencial, em parte parecido com o de Tomás, porém com grande teor de autoflagelação, porque ele se considera tomado pelo medo, pela tristeza e pela solidão. Um aspecto abordado por ele, que também surgiu em outros discursos da etnografia em Nagafuchi (2017), foi o medo de uma institucionalização na forma de internação hospitalar ou em clínicas especializadas. Embora alguns estudos da Psicologia e da Medicina apontem uma correlação entre tentativas de suicídio e transtornos de saúde mental oficialmente catalogados, estes sujeitos da pesquisa raramente se viam doentes - no sentido da oposição clássica da doxa da Saúde (saúde vs. doença) -, muito menos como portadores de transtornos mentais. Há, inclusive, pesquisas 
da genética que buscam mapear genes que influenciariam os sistemas dopaminérgicos e serotonérgicos e, como consequência, seriam responsáveis por um aumento da probabilidade de suicídio em sujeitos que os portam. O lugar do suicídio nas áreas clássicas da Saúde deve passar por uma reflexão crítica e, se possível, com aporte das ciências humanas, por conta do risco de incorrer em deduções stricto sensu, sem conexão com a realidade ou com o cotidiano das pessoas. Tal discussão é necessária e urgente.

E, além disso, em acordo com a proposta do artigo de trazer outras formas de entender o suicídio, considerando-o como ato de comunicação das violências e dos sofrimentos sociais que afligem as subjetividades e as experiências de estar-no-mundo dos sujeitos, fazse necessário e urgente, também, repensar e ressignificar os modos de fazer prevenção e de desenhar protocolos de atendimento daqueles que tentam o suicídio - como redução de danos, uma vez que nesta visão, o suicídio é parte constituinte do social e do cultural e, portanto, é parte intrínseca da vida. Contudo, isso só pode acontecer se os profissionais da área de Saúde tiverem uma parte da formação e da educação continuada voltada às ciências humanas, passando pelos modos de compreender sociológicos até os significados produzidos pelos estudos etnográficos e pelos conceitos antropológicos do suicídio.

Uma última análise, levando em consideração a antropologia do devir. O devir se esconde nas palavras, porém, é revelado na experiência do cotidiano. Mesmo que as formas de vida thes sejam negadas, como um futuro imaginado, os interlocutores continuam buscando modos de repensar as próprias subjetividades no cotidiano para continuarem na vida. Antônio, em meados de 2018, declarou que estaria entrando na política e se apresentou como candidato ao legislativo do seu estado, Tomás, da última vez que nos falamos, disse que tinha acabado de ser aprovado em um doutorado na Alemanha. Os sujeitos vão buscando maneiras de atravessar o emaranhado de sofrimento. É neste atravessamento que se dá o devir e onde se exerce a plasticidade.

Por fim, é de extrema importância enunciar que todos os casos de suicídio demandam empatia e alteridade. Não se deve fazer julgamentos apressados e com base no senso comum. Um tratamento responsável e respeitoso deve, no mínimo, partir de uma escuta empática. Isto é dito porque o exercício de alteridade só se torna possível por meio da linguagem; uma vez que é impossivel sentir a dor do outro, só resta conhecê-la por meio da possibilidade da comunicação quando esta se estabelece (Das, 2007; 2015). Quando se nega a dor do outro, incorre-se no risco de negar o outro da própria vida.

\section{Referências Bibliográficas}

ADORNO, Rubens de Camargo Ferreira. Prefácio: Pelo direito de morrer. In: MARQUETTI, Fernanda Cristina. Suicídio: escutas do silêncio. São Paulo: Editora UNIFESP, p. 9-13, 2018.

AGAMBEN, Giorgio. Homo Sacer: O Poder Soberano e a Vida Nua I. $2^{\underline{a}}$ ed. Belo Horizonte: Editora UFMG, 2012. 197p.

ARIĖS, Philippe. The Hour of Our Death: The classic history of western attitudes toward death over the last one thousand years. New York: Vintage Books, 1981. 696p. 
BIEHL, João. VITA: Life in a Zone of Social Abandonment. Berkeley: University of California Press, 2005. 404p.

BIEHL, João. A Life: Between Psychiatric Drugs and Social Abandonment. In: BIEHL, João; GOOD, Byron \& KLEINMAN, Arthur. Subjectivity: Ethnographic Investigations. Berkeley: University of California Press, p. 397-421, 2007.

BIEHL, João. Antropologia do Devir: Psicofármacos - Abandono Social - Desejo. Revista de Antropologia da USP. São Paulo, v. 51, n. 2, p. 413-49, 2008.

BIEHL, João \& LOCKE, Peter. Unfinished: The Anthropology of Becoming. London: Duke University Press, 2017. 400p.

CAVELL, Stanley. Comments on Veena Das's Essay 'Language and Body: Transactions in the Construction of Pain'. In: KLEINMAN, Arthur; DAS, Veena \& LOCK, Margaret. Social Suffering. Berkeley: University of California Press, 1997.

DAS, Veena. Life and Words: Violence and the Descent into the Ordinary. Berkeley: University of California Press, 2007. 296p.

DAS, Veena. Adjacent Thinking: A Postscript. In: CHATTERJI, Roma. Wording the World: Veena Das and Scenes of Inheritance (Forms of Living). New York: Fordham University Press, p. 372399, 2015

DURKHEIM, Emile. O Suicídio. São Paulo: Editora Martin Claret, 2008. 552p.

FASSIN, Didier. Ethics of Survival: A Democratic Approach to the Politics of Life. Humanity. Philadelphia, v. 1, n. 1, p. 81-95, 2010.

FASSIN, Didier. The Parallel Lives of Philosophy and Anthropology. In: DAS, Veena et al. (Ed.). The Ground Between: Anthropologists Engage Philosophy. Durham: Duke University Press, p. 50-70, 2014.

FASSIN, Didier. The Value of Life and the Worth of Lives. In: DAS, Veena \& HAN, Clara (Eds.). Living and Dying in the Contemporary World: A Compendium, Oakland: University of California Press, p. 770-782, 2016.

FASSIN, Didier. Life: A Critical User's Manual. Cambridge: Polity Press, 2018. 158p.

FAULKNER, Thomas. Absalão, Absalão! São Paulo: Cosac Naify, 2014. 352p.

FISCHER, Michael M. J. Epilogue: To Live with What Would Otherwise be Unendurable: Return(s) to Subjectivity. In: BIEHL, João; GOOD, Byron \& KLEINMAN, Arthur (Eds.). Subjectivity: Ethnographics Investigations. Berkeley: University of California Press, 423-446, 2007.

GIDDENS, Anthony. A Transformação da Intimidade: Sexualidade, Amor e Erotismo nas Sociedades Modernas. São Paulo: Editora UNESP, 1993. 228p.

GUILLON, Claude e LE BONNIEC, Yves. Suicídio: Modo de usar, história, técnica e notícia. Lisboa: Ed. Antígona, 1990. 305p.

KLEINMAN, Arthur; DAS, Veena \& LOCK, Margaret. Social Suffering. Berkeley: University of 
California Press, 1997. 464p.

KLEINMAN, Arthur; FITZ-HENRY, Erin. The Experiential Basis of Subjectivity: How Individuals Change in the Context of Societal Transformation. In: BIEHL, João; GOOD, Byron \& KLEINMAN, Arthur (Eds.). Subjectivity: Ethnographics Investigations. Berkeley, University of California Press, P. 52-65, 2007.

LOCK, Margaret. Twice Dead: Organ Transplants and the Reinvention of Death. Berkeley: University of California Press, 2002. 429p.

MALINOWSKI, Bronislaw. Magic, Science and Religion, In: ROBBEN, Antonius C.G.M. (Ed.). Death, Mourning, and Burial: A Cross-Cultural Reader. Malden: Blackwell Publishing, 2004.

MARQUETTI, Fernanda Cristina. O Suicídio como Espetáculo na Metrópole de São Paulo. São Paulo: Editora UNIFESP, 2012. 248p.

MARQUETTI, Fernanda Cristina. O Suicídio e sua essência transgressora. Psicologia USP. São Paulo, v. 25, p. 237-245, 2014.

MARQUETTI, Fernanda Cristina. As Noivas Vermelhas, In: (Org). Suicídio: escutas do silêncio. São Paulo: Editora UNIFESP, p. 177-202, 2018.

MARX, Karl. Sobre o Suicídio. São Paulo: Boitempo, 2006. 84p.

MAUSS, Marcel. Sociologia e Antropologia. São Paulo: Cosac Naify, 2003. 542p.

MINOIS, Georges. History of Suicide: Voluntary Death in Western Culture. Baltimore: The Johns Hopkins University Press, 1999. 400p.

NAGAFUCHI, Thiago e ADORNO, Rubens de Camargo Ferreira. Suicídio, Gênero e Sexualidade na Era Digital. Saúde \& Transformação Social. Florianópolis, v. 7, n. 3, p. 22-35, 2016.

NAGAFUCHI, Thiago. Um réquiem feito de silêncios: suicídio, gênero e sexualidade na era digital. Tese (Doutorado em Saúde Pública). Programa de Pós-Graduação em Saúde Pública, Universidade de São Paulo, São Paulo, 2017. 217p.

NAGAFUCHI, Thiago. Em busca de vozes no silêncio: suicídio, gênero e sexualidade na era digital. In: MARQUETTI, Fernanda Cristina (Org.). Suicídio: escutas do silêncio. São Paulo: Editora UNIFESP, p. 147-55, 2018.

OZAWA-DE SILVA, Chikako. Too Lonely to Die Alone: Internet Suicide Pacts and Existential Suffering in Japan. Culture, Medicine and Psychiatry. On-line, v. 32, n. 4, p. 516-551, 2008.

OZAWA-DE SILVA, Chikako. Shared Death: Self, Sociality and Internet Group Suicide in Japan. Transcultural Psychiatry. Montreal, v. 43, n. 3, p. 392-418, 2010.

RONDELLI, Elizabeth e HERSCHMANN, Micael. A mídia e a construção do biográfico: o sensacionalismo da morte em cena. Tempo Social; Revista de Sociologia da USP. São Paulo, v. 12, n. 1. p. 201-228, 2000.

SILVA, Nathalia Ramos e MENEZES, Rachel Aisengart. "Se parar, parou": categorização do morrer em uma unidade de terapia intensiva da cidade do Rio de Janeiro. Physis: Revista de 
Saúde Coletiva. Rio de Janeiro, v. 25, n. 1, p. 265-285, 2015.

SOLOMON, Andrew. O Demônio do meio-dia: Uma anatomia da depressão. São Paulo: Companhia das Letras, 2014. 584p.

STAPLES, James \& WIDGER, Tom. Situating Suicide as an Anthropological Problem: Ethnographic Approaches to Understanding Self-Harm and Self-Inflicted Death. Culture, Medicine and Psychiatry. On-line, v. 36, n. 2, p. 183-203, 2012.

WIDGER, Tom. Suffering, Frustration, and Anger: Class, Gender and History in Sri Lankan Suicide Stories. Culture, Medicine and Psychiatry. On-line, v. 36, n. 2, p. 225-244, 2012.

Enviado em: 30 de outubro de 2018.

Aprovado em: 19 de maio de 2019. 